\title{
Changes in the expression of cell cycle regulators during rat liver regeneration after partial hepatectomy
}

\author{
Hyeseong Cho ${ }^{1}$, In Kyoung Lim ${ }^{1}$ and \\ Jae-Ho Lee ${ }^{1,2}$ \\ 1 Department of Biochemistry, School of Medicine, Ajou University, \\ Suwon 442-749, Korea \\ 2 Corresponding author
}

Accepted 4 December 1996

Abbreviations: Cdk, cyclin-dependent kinase; TBS, Tris-buffered saline; CKI, cyclindependent kinase inhibitor

\begin{abstract}
The changes of cell cycle regulators which may trigger $G_{0}$ to $G_{1}$ transition during liver regeneration have been examined. In vivo thymidine uptake indicated that $S$ phase began about $18 \mathrm{~h}$ and the peak of DNA synthesis appeared from 21 to $24 \mathrm{~h}$ after partial hepatectomy. Various time-points from $\mathrm{G}_{0}$ to mid-S-phase were selected within $24 \mathrm{~h}$ after partial hepatectomy and the expression levels of cyclins, cyclin-dependent kinase (Cdk) and cyclindependent kinase inhibitors (CKIs) were examined by Northern and Western analysis. Both cyclin D1 mRNA and protein increased at $15 \mathrm{~h}$ after operation. Cyclin E mRNA was first detected at $12 \mathrm{~h}$ and continued to increase until $21 \mathrm{~h}$, whereas expression of cyclin B mRNA was first observed at $21 \mathrm{~h}$. Expression of Cdk4 mRNA in normal rat liver was clearly detectable, increased significantly at 9 $h$ after resection, and remained increased up to 24 h. On the other hand, an increase in Cdk4 protein was observed as early as $3 \mathrm{~h}$ after the surgery and reached plateau at $18 \mathrm{~h}$. We next examined expression of CKIs which may regulate activity of cyclin/Cdk complex during liver regeneration. p27 ${ }^{\mathrm{KIP} 1}$ protein was detected in normal rat liver whereas p21 ${ }^{\mathrm{CIP} 1}$ protein was not. Expression of p2 $1^{\text {CIP1 }}$ protein appeared as early as $3 \mathrm{~h}$ and continued to increase up to $21 \mathrm{~h}$. Expression of p27 ${ }^{\mathrm{KIP} 1}$ protein, however, increased slightly until 24 h.
\end{abstract}

Keywords: cell cycle, cyclin-dependent kinases, cyclins, cyclin-dependent kinase inhibitors, partial hepatectomy, rat, liver

\section{Introduction}

Liver regeneration following $70 \%$ partial hepatectomy offers an unique in vivo system to study gene regulation and cell cycle processes in differentiated, nontransformed cells (Fausto et al., 1994). After resection of the left lateral and median lobes of the rat liver, the remaining hepatocytes and nonparenchymal cells synchronously exit from their $\mathrm{G}_{0}$ state and enter $\mathrm{G}_{1}$, and the cell cycle is marked by a pattern of induction of many proto-oncogenes, cyclins, and cyclindependent kinases (Cdks). Analysis of a variety of systems indicate that the Cdks, complexed with appropriate cyclin molecules, play major roles in cell cycle progression in all eukaryotic cells (Granar and Reddy,1995). The activities of Cdks are controlled by highly conserved biochemical mechanisms, and activation by cyclin binding and inhibition by $\mathrm{Cdk}$ inhibitors are two prominent mechanisms (Morgan, 1995).

There have been some reports on the changes of the regulatory mechanism involving $\mathrm{G}_{1}$ phase cyclins, cyclin $D$ and cyclin $E$ during this remarkable period of synchronous restart of hepatocyte proliferation. The expression of mRNAs of cyclin D1 and cyclin E (two major cyclin proteins in $\mathrm{G}_{1}$ phase) was reported to increase after partial hepatectomy (Lu et al., 1992; Loyer et al., 1994; Albrecht et al., 1995). However, protein levels of cyclin D1 and cyclin E were found to be almost the same after partial hepatectomy (Loyer et al., 1994; Albrecht et al., 1995), and an association of Cdk4 and cyclin D1 was also the same (Albrecht et al., 1995).

There are a diverse family of proteins termed Cdk inhibitors (CKIs) that bind and inactivate Cdk-cyclin complexes. $\mathrm{p} 21^{\mathrm{CIP} 1}$ and $\mathrm{p} 27^{\mathrm{KIP} 1}$ are the best known CKIs showing change in the amount during $G_{0}$ to $G_{1}$ transition in in vitro systems (Sherr, 1994). However, there has been no report yet on the changes of CKIs during rat liver regeneration after partial hepatectomy.

Although it was reported that there are no significant changes in the levels of cyclin D1 and E and association properties of cyclin D1 and Cdk4 during rat liver regeneration, we expected some changes in the activities of cyclin D1- or E-dependent kinases through changes in either Cdk itself or Cdk activators or Cdk inhibitors such as $\mathrm{p} 21^{\mathrm{CIP} 1}$ families. In order to test this hypothesis, we have investigated herein changes in the amounts of cyclin D1, Cdk4 and CKIs such as p21 CIP1 and $p 27^{\mathrm{KIP} 1}$ during $\mathrm{G}_{0}$ to $\mathrm{G}_{1}$ to $S$ transition in rat liver cells after $70 \%$ partial hepatectomy. 


\section{Materials and Methods}

\section{Animals and surgical procedures}

Seventy-percent partial hepatectomy surgeries were performed on 200-220 g male Sprague-Dawley rats (Korea Laboratory Animal Center, raised in specificpathogen-free condition) under ether anesthesia according to the method of Higgins and Anderson (1931). At various times after partial hepatectomy, perfusion with normal saline through portal vein was performed, liver tissue was removed, and the tissue was snap frozen in liquid nitrogen. Sham-operated rats were treated almost the same except the liver was not excised.

\section{Antibodies}

Antisera and monoclonal antibodies used in these studies are as follows; monoclonal anti-cyclin D1 (G124-326, Pharmingen, U.S.A.), polyclonal anti-Cdk4 (sc-260, Santa Cruz, U.S.A.), polyclonal anti-p21 CIP1 (Ab-5, Oncogene, U.S.A.), anti-cyclin D1 monoclonal antibody-conjugated agarose(sc-450 AC, Santa Cruz), and polyclonal anti-p27 ${ }^{\mathrm{KIP} 1}$ (sc-528, Santa Cruz).

\section{In vivo thymidine uptake}

In vivo thymidine uptake was measured according to the method of Terasaki et al. (1991). One hour before sacrifice, ${ }^{3} \mathrm{H}$-thymidine in PBS $(30 \mu \mathrm{Ci} / 200 \mu \mathrm{l} / 100 \mathrm{~g}$ body weight) was injected into hepatectomized or sham-operated rats intraperitoneally. One hour later, the liver was perfused with normal saline through portal vein. Remnant liver was excised and trichloroacetic acid-precipitatable radioactivity was measured.

\section{Northern blot analysis}

Total RNA was isolated using the guanidinium thiocyanate-phenol-chloroform method (Chomczynski and Sacchi, 1987). Twenty $\mu \mathrm{g}$ of total RNA was separated on a formaldehyde-denaturing gel and transferred to a nitrocellulose membrane. Transferred RNA was hybridized with ${ }^{32} \mathrm{P}$-labelled probe cDNAs, and the membrane were exposed to x-ray film. cDNAs of cyclins, Cdk4 and CKIs were kindly provided by Dr. Gou-Young Koh, Chonbuk National University, Chonju.

\section{Western blot analysis}

After homogenization in $40 \mathrm{mM}$ Tris buffer, $\mathrm{pH}$ 8.0, containing $120 \mathrm{mM} \mathrm{NaCl}$ and $0.5 \% \mathrm{NP}-40$ with protease inhibitors $(100 \mu \mathrm{g} / \mathrm{ml}$ phenylmethylsulfonyl fluoride, and $1 \mu \mathrm{g} / \mathrm{ml}$ leupeptin), the samples were centrifuged at $10,000 \mathrm{~g}$ for $15 \mathrm{~min}$ and the supernatant was used for Western blot analysis. Western blot experiments were carried out in Towbin buffer (182 mM glycine, $24 \mathrm{mM}$ Tris, and $20 \%$ methanol) with a nitrocellulose membrane (Harlow and Lane, 1988). Following the transfer, blots were blocked either for $1 \mathrm{~h}$ at room temperature or overnight at $4^{\circ} \mathrm{C}$ in $5 \%(\mathrm{w} / \mathrm{v})$ non-fat dried milk (Seoul Milk, Korea) and TBS (20 mM Tris, $137 \mathrm{mM} \mathrm{NaCl} \mathrm{pH} \mathrm{7.6).} \mathrm{Secondary} \mathrm{antibodies}$ conjugated with horseradish peroxidase were used, and immunoreactive proteins were detected using enhanced chemiluminescence (Amersham, U.K.). After the exposure, the filter papers were stained with $0.1 \%$ $(\mathrm{w} / \mathrm{v})$ Ponceau $S$ staining solution in $5 \%$ acetic acid (v/v) (Sigma, U.S.A.) to compare the amounts of proteins transferred.

\section{Immunoprecipitation}

Frozen tissue was homogenized in $40 \mathrm{mM}$ Tris buffer, $\mathrm{pH} 8.0$, containing $120 \mathrm{mM} \mathrm{NaCl}$ and $0.5 \% \mathrm{NP}-40$ with protease inhibitors $(100 \mu \mathrm{g} / \mathrm{ml}$ phenylmethylsulfonyl fluoride, and $1 \mathrm{~g} / \mathrm{ml}$ leupeptin), the samples were centrifuged at $10,000 \mathrm{~g}$ for $15 \mathrm{~min}$ and the supernatant was precipitated for $3 \mathrm{~h}$ at $4^{\circ} \mathrm{C}$ with anti-cyclin D1 antibody-conjugated agarose beads. Beads were washed with the same buffer used in homogenization, suspended with SDS sample buffer, and Western blot analysis was performed with anti-cyclin D1 antibody (Pharmingen).

\section{Protein determination}

The protein concentration of the samples was measured by BCA analysis (Pierce, U.S.A.), using bovine serum albumin as a standard.

\section{Results and Discussion}

Our present study focused on the changes of cell cycle regulators which would be associated with $G_{0}$ to $G_{1}$ transition during liver regeneration. Various time points were selected within $24 \mathrm{~h}$ after partial hepatectomy, namely from $\mathrm{G}_{0}$ to mid-S phase, and the expression levels of various $G_{1}$ cell cycle regulators were measured.

\section{In vivo thymidine uptake}

In vivo thymidine uptake was performed to examine the kinetics of cell cycle progression. As shown in Figure 1, the time course of ${ }^{3} \mathrm{H}$-thymidine incorporation in livers of these animals confirmed the high synchrony during the first round of division of the hepatocyte population, indicating maximum DNA synthesis at 22-24 h (Loyer et al., 1994). No ${ }^{3} \mathrm{H}$-thymidine incorporation was found during the first $15 \mathrm{~h}$ after partial hepatectomy, and a dramatic increase of DNA synthesis took place after 18 $\mathrm{h}$, peaking at 21-24 $\mathrm{h}$. Therefore, we were able to delineate the $G_{0}$ to $G_{1}$ from the start of regeneration to $18 \mathrm{~h}$ and $\mathrm{S}$ phase after $18 \mathrm{~h}$ of partial hepatectomy. This enabled us to proceed to analyze changes of cell 


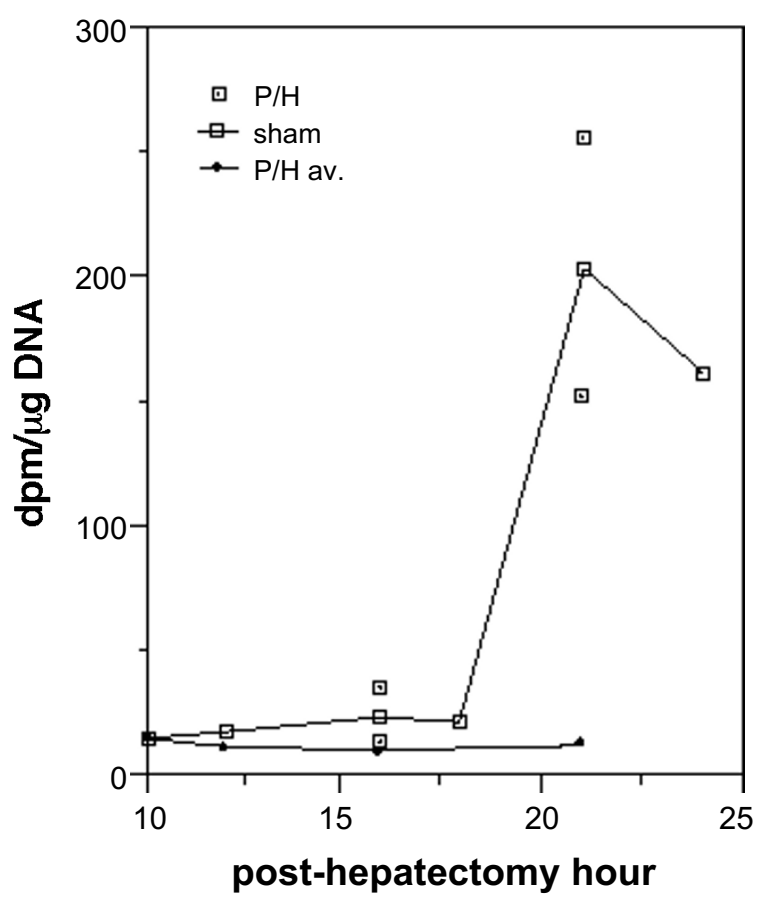

Figure 1. Time course of in vivo $\left\{{ }^{3} \mathrm{H}\right\}$-thymidine uptake during liver regeneration. At different times after partial (two-thirds) hepatectomy, rats were injected with $\left[{ }^{3} \mathrm{H}\right]$ thymidine $(30 \mu \mathrm{Ci} / 200 \mu \mathrm{l} / 100 \mathrm{~g}$ body weight) $1 \mathrm{~h}$ before sacrifice. Livers were perfused with normal saline through portal vein and the radioactivity in remnant liver was determined by trichloroacetic precipitation. $\left[{ }^{3} \mathrm{H}\right]$ thymidine incorporation into DNA was expressed as counts (dpm) per $\mu \mathrm{g}$ DNA. $\mathrm{P} / \mathrm{H}$, individual value of partial hepatectomy group; sham, sham-operated group; $\mathrm{P} / \mathrm{H}$ av., average value of partial hepatectomy group.

cycle regulators during this mammalian cell cycle.

\section{Expression of mRNA of various cyclins and Cdk4}

As shown in Figure 2, the mRNA expression of cyclin $D 1$ and cyclin $E$ increased before $S$ phase started, and reached a plateau during $S$ phase. The expression of cyclin B, a well-known cyclin for entry into mitosis, began to be detected $22 \mathrm{~h}$ after partial hepatectomy. It seems somewhat contradictory that the expression of cyclin $E$, a cyclin known to be important in $G_{1} / S$ transition, precedes that of cyclin D1 which acts during mid- to late $G_{1}$ phase. Because the similar phenomenon has also been described previously by Lu et al. (1992) during liver regeneration after partial hepatectomy, it may be due to the discrepancy between transcription and translation. In the case of Cdk4, mRNA expression was detected in normal rat liver and increased from $9 \mathrm{~h}$ after partial hepatectomy.

\section{Changes in cyclin D1 and Cdk4 protein}

Contrary to the other's report (Albrecht et al., 1995),

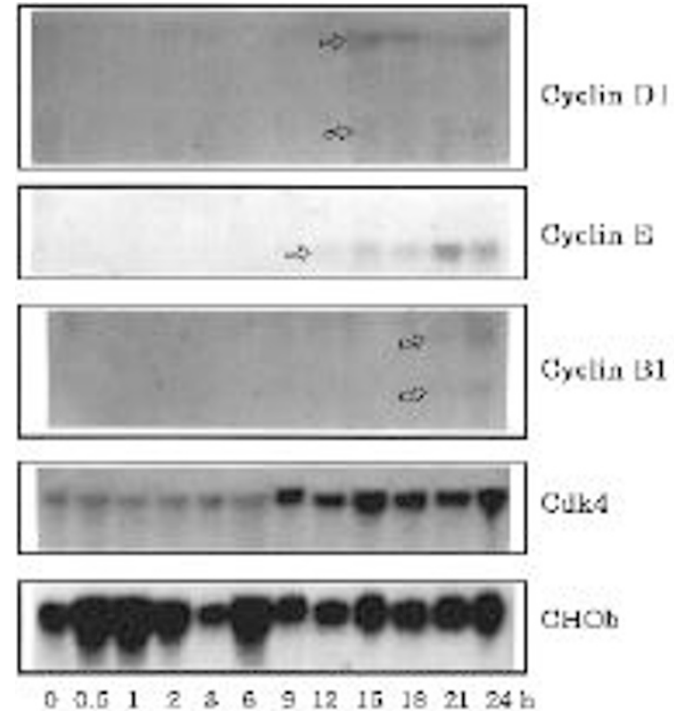

Figure 2. Changes in cyclin and cyclin-dependent kinase 4 (Cdk4) mRNA expression. Total RNAs were isolated from the rat liver at various time points $(0-24 \mathrm{~h})$ after partial hepatectomy. Twenty $\mu \mathrm{g}$ of total RNA at each time point was analyzed for mRNA expression of cyclins and Cdk4 by Northern blot analysis. CHOb mRNA (Lim et al., 1994) is shown for normalization of mRNA content on each lane.

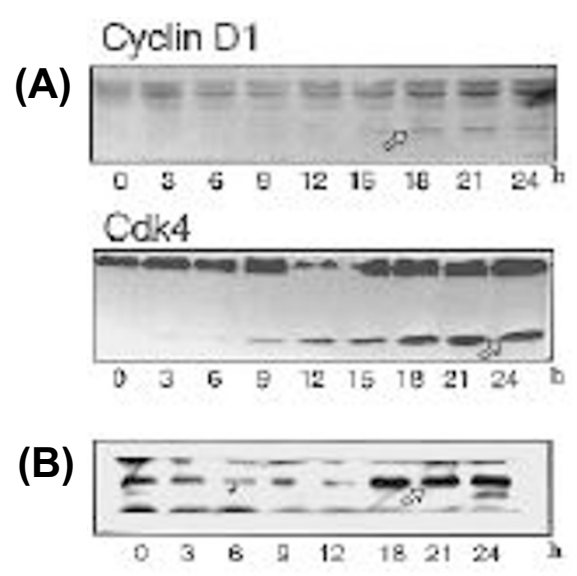

Figure 3. Changes in cyclin D1 and Cdk4 proteins. Tissue homogenates were prepared from the rat liver at various time points $(0-24 \mathrm{~h})$ after partial hepatectomy. (A) Homogenates at each time point were subjected to SDS-PAGE and immunoblot analysis was performed using anti-cyclin D1 antibody and anti-Cdk4 antibody. Each arrow denotes specific protein bands. (B) Homogenates were subjected to immunoprecipitation using anti-cyclin D1 antibody-conjugated agarose (sc-450 AC) followed by SDS-PAGE and immunoblot analysis using same anti-cyclin D1 antibody (G124-326) used in A.

cyclin D1 protein level did not remain unchanged but rather increased after $15 \mathrm{~h}$ of partial hepatectomy shown by Western analysis of whole lysate (Figure 3A). In order to verify the validity of the results, immunoprecipitation followed by Western blot analysis was 
performed. Another anti-cyclin D1 antibody (sc-450AC) was used as an immunoprecipitating agent. The increase of cyclin D1 protein was also clearly observed (Figure 3B).

The Cdk4 protein level increased sharply during the $24 \mathrm{~h}$ period (Figure 3 ), showing good correlation with its mRNA expression. This result together with Cdk4 mRNA expression (Figure 2) seems somewhat different from the results obtained by Albrecht et al. (1995). They reported that both Cdk4 mRNA and protein level showed little variation during regeneration of rat liver. However, the anti-Cdk4 antibody used here could detect protein band of same molecular weight after immunoprecipitating with anti-cyclin D1 antibody (Lee et al., 1996, manuscript in preparation).

\section{Changes in $\mathrm{p} 21^{\mathrm{CIP} 1}$ and $\mathrm{p} 27^{\mathrm{KIP} 1}$ expression}

Our hypothesis was to find a decrease of the expression of CKIs during $\mathrm{G}_{0}$ to $\mathrm{G}_{1}$ transition. However, as shown in Figure 4, neither p2 ${ }^{\mathrm{CIP} 1}$ nor p $27^{\mathrm{KIP} 1}$ protein decreased during $G_{0}$ to $G_{1}$ transition period. Rather, p21 ${ }^{\mathrm{ClP} 1}$ clearly increased and $\mathrm{p} 27^{\mathrm{KIP} 1}$ showed slight increase. It has been shown that, though it was the observation in normal human fibroblasts, the levels of p $21^{\mathrm{CIP} 1}$ mRNA peaked twice, during $\mathrm{G}_{1}$ and $\mathrm{G}_{2} / \mathrm{M}(\mathrm{Li}$ et al., 1994), and the expression of $\mathrm{p} 27^{\mathrm{KIP} 1}$ was high in $\mathrm{G}_{0}$ period followed by a decrease during $\mathrm{G}_{0}$ to $\mathrm{G}_{1}$ transition (Sherr, 1994). The increase of both CKIs during liver regeneration may be a liver-specific phenomenon.

It has been proposed earlier that the net levels of both $\mathrm{p} 21^{\mathrm{CIP} 1}$ and $\mathrm{p} 27^{\mathrm{KIP} 1}$ proteins set an 'inhibitory
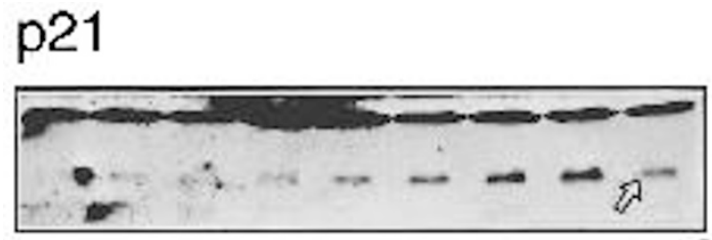

$\begin{array}{llllllllll}0 & 3 & 6 & 9 & 12 & 15 & 18 & 21 & 24 & \text { h }\end{array}$

\section{p27}

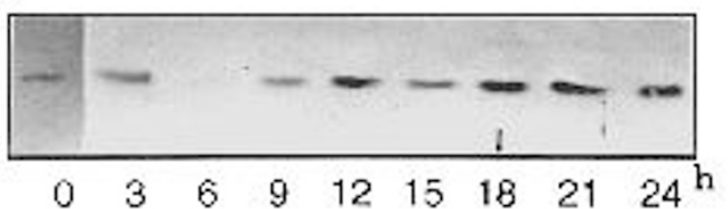

Figure 4. Changes in $\mathrm{p} 21^{\mathrm{CIP} 1}$ and $\mathrm{p} 27^{\mathrm{KIP} 1}$ expression. Tissue homogenates of regenerating livers were subjected to $15 \%$ SDS-PAGE and subsequently analyzed for the expression of $\mathrm{p} 21^{\mathrm{CIP} 1}$ and $\mathrm{p} 27^{\mathrm{KIP} 1}$ proteins by immunoblot analysis. Arrow denotes specific protein bands. threshold' (Sherr, 1994). The progressive increase in cyclin D/Cdk4 complexes during $G_{1}$ titrates the inhibitors, which repress the activity of the holoenzyme until cyclin D/Cdk4 levels exceed the inhibitory threshold. On the basis of such a model, the increase of cyclin D1 and Cdk4 after partial hepatectomy seems to indicate more production of cyclin $\mathrm{D} / \mathrm{Cdk} 4$ holoenzyme which can titrate increased p $21^{\mathrm{CIP} 1}$ and p2 ${ }^{\mathrm{KIP} 1}$ proteins, thereby enabling the critical regulator of $G_{1} / S$ transition, cyclin $E / C d k 2$, to perform their role in proceeding to a new round of cell cycle.

\section{Acknowledgements}

This work was supported by Korean Ministry of Education through Research Fund (J. H. L., Project No; 96-126) and in part by grant from Ajou Medical Institute (J. H. L). We thank deeply Dr. Gou-Young Koh (Chonbuk National University) for providing cDNAs and Dr. Woon Ki Paik for his critical review of this manuscript.

\section{References}

Albrecht, J. H., Hu, M. Y. and Cerra, F. B. (1995) Distinct patterns of cyclin D1 regulation in models of liver regeneration and human liver. Biochem. Biophys. Res. Commun. 209: 648-655

Chomczynski, P. and Sacchi, N. (1987) Single-step method of RNA isolation by acid guanidinium thiocyanate phenol-chloroform extraction. Anal. Biochem. 162: 156-159

Fausto, N. and Webber, E. M. (1994) Liver regeneration. In The Liver: Biology and Pathobiology (Arias, I. M., Boyer, J. L., Fausto, N., Jokoby, W. B., Schachter, D. and Shafritz, D. A., eds.), pp.1059-1084, Raven press, New York

Grana, X. and Reddy, E. P. (1995) Cell cycle control in mammalian cells: role of cyclins, cyclin dependent kinases(Cdks), growth suppressor genes and cyclindependent kinase inhibitors(CKIs). Oncogene 11: 211-219

Harlow, E. and Lane, D. (1988) Antibodies. A laboratory Manual. pp. 479-510, Cold Spring Harbor Laboratory, New York

Higgins, G. M. and Anderson, R. M. (1931) Experimental pathology of the liver; Restoration of the liver of the white rats following partial surgical removal. Arch. Pathol. 12: $186-202$

Lim, I. K., Kim, N. K., Lee, M. S. and Lee, S. H. (1994) Expression of TIS-21 gene during the development of Balb/c mice and the liver regeneration. Korean J. Biochem. 26: $169-175$

Loyer, P., Glaise, D., Cariou S., Baffet, G., Meijer, L. and Guguen-Guillouzo, C. (1994) Expression and activation of Cdks(1 and 2) and cyclins in the cell cycle progression during liver regeneration. J. Biol. Chem. 269: 2491-2500

Lu, X. P., Koch, K. S., Lew, D. J., Dulic, V., Pines, J., Reed, S. I., Hunter, T. and Leffert, H. L. (1992) Induction of cyclin mRNA and cyclin-associated histone Hi kinase during liver regeneration. J. Biol. Chem. 267: 2841-2844

Li, Y., Jenkins, C. W., Nichols, M. A. and Xiong, Y. (1994) Cell cycle expression and p53 regulation of the cyclin-dependent kinase inhibitor p21. Oncogene 9: 2261-2268

Morgan, D. O. (1995) Principles of Cdk regulation. Nature 374: 131-134

Sherr, C. J. (1994) $\mathrm{G}_{1}$ phase progression: cycling on cue. Cell 79: 551-555 
Terasaki, M., Kuriki, H., Nimura, Y., Shionoya S., Kojima, K. and Yoshida, S. (1991) Induction of DNA replication and cell growth in rat liver by obstructive jaundice. Jpn. J. Cancer Res. 82: 170-175 